


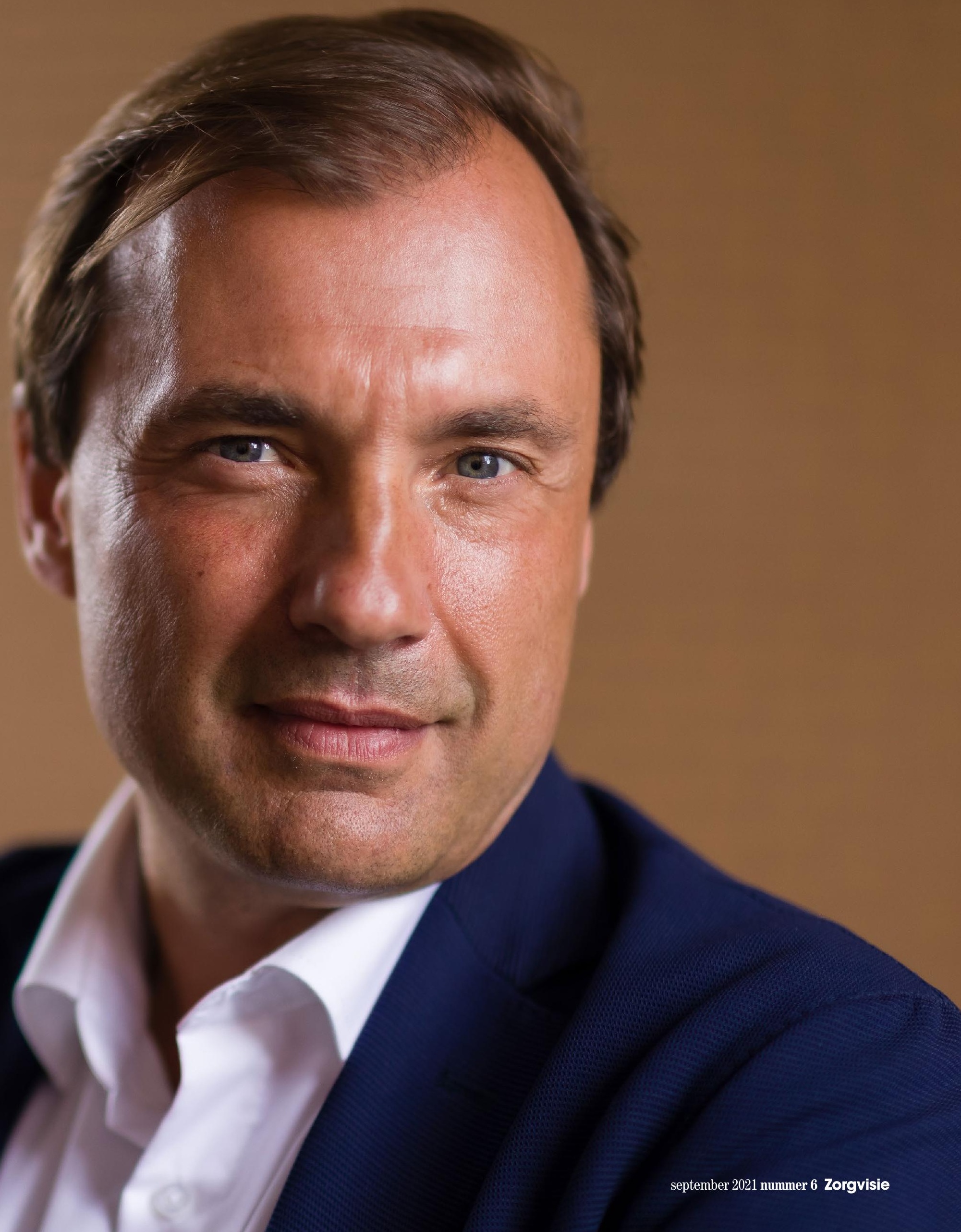


12 OMT-lid Alex Friedrich werd bekend bij een groot publiek als voorvechter van 'testen, testen, testen'. Als aankomend bestuursvoorzitter van het Universitätsklinikum Münster wil hij Europa op zijn grondvesten laten trillen met grensoverschrijdende zorg. 'Gebruik de overcapaciteit in Duitsland en België.'

Het is de verjaardag van Alex Friedrich, UMCG-arts en microbioloog, 23 februari 2020. Op die dag drukt hij op de alarmknop in het UMCG. Het coronavirus komt eraan en Nederland is daar niet goed op voorbereid.

In Nederland, en de rest van Noord-West Europa, ontbreekt dan nog het gevoel van urgentie. Wat er in China gebeurt, is lastig te duiden. En de Italianen? Die overdrijven altijd. Zo denken beleidsmakers in West-Europa. Maar Friedrich spreekt via zijn internationale netwerk artsen in de brandhaarden. Hij zit in het bestuur van de Europese vereniging van medische microbiologen. Bovendien hoort hij verslagen van ooggetuigen in Italië; Friedrich heeft familie in Italië en spreekt vloeiend Italiaans. 'Dokters in Noord-Italië zagen golven van patiënten op de spoedopvang en de IC afkomen. Dat waren bevriende artsen die ik vertrouw. Ik werd er nerveus van, want Nederland had toen de helft van het aantal IC-bedden in Noord-Italië. Ik wist dat het coronavirus Nederland hard zou raken. Nuchterheid is goed, maar die heeft ons in het begin kostbare tijd gekost. Je moet wel op tijd op de alarmknop drukken.'

\section{Testen, testen, testen}

Friedrich, die dan ook voorzitter is van het stafconvent in het UMCG, weet het UMCG te overtuigen om veel laagdrempeliger te gaan testen. In de rest van Nederland worden dan alleen patiënten getest die uit China komen en 38,5 graden koorts hebben. 'In calls met Italiaanse collega's werd me duidelijk dat 90 procent van de coronapatiënten in Italië die kenmerken niet had. Met ons beleid in
Nederland zouden we die coronapatiënten dus ook niet zien. Er kwam een enorme golf op ons af die onder de radar bleef. Dan moet je alertheid creëren.'

Friedrich spreekt de leidinggevenden in het UMCG toe: 'Jullie lachen me misschien uit over twee maanden. Maar ik wil niet dat we dan zeggen: "Hadden we maar eerder gereageerd".' Testen, testen, testen, wordt het motto in Noord-Nederland. Ook medewerkers met lichte klachten moeten zich laten testen. Werknemers die van vakantie terugkomen, mogen pas na een negatieve test aan de slag in het ziekenhuis. 'In Italië zag je dat verspreiding via het zorgpersoneel voor het coronavirus een belangrijke snelweg was. Dat moet je voorkomen met laagdrempelig testen en mondmaskers.'

Friedrich heeft in vredestijd veel geïnvesteerd in het regionale netwerk voor de preventie van infecties. Dat betaalt zich nu terug. Andere zorgaanbieders in Noord-Nederland volgen hetzelfde beleid. De aanpak werkt. In één week testen zelfs 500 zorgmedewerkers in Noord-Nederland positief. 'Als collectief van ziekenhuizen, verpleeghuizen en revalidatiecentra kun je veel bereiken om de verspreiding af te remmen. Het is funest als ieder ziekenhuis zijn eigen gang gaat.'

\section{Kritiek}

Er is wel een mismatch met het landelijke beleid. Minister Hugo de Jonge van VWS uit aanvankelijk kritiek op de afwijkende aanpak in Noord-Nederland. Wees zuinig op het testmateriaal, want er is een landelijk tekort, luidt de boodschap uit Den Haag. Friedrich negeert die welbewust. 'Als het landelijke beleid een risico vormt voor mijn patienten en medewerkers, dan wijk ik daarvan af. Uiteindelijk ben ik medisch verantwoordelijk. Je moet in die vroege fase al het testmateriaal inzetten om de verspreiding maximaal af te remmen. Twee maanden wachten is in een pandemie een eeuwigheid. Bovendien was er helemaal geen tekort, het was een logistiek probleem. Dat heeft de Algemene Rekenkamer later ook vastgesteld.' Later trekt de minister zijn kritiek in en wordt zo veel mogelijk testen landelijk beleid. En in april wordt Friedrich gevraagd toe te treden tot het OMT. Dankbaar werk, maar Friedrich ervaart ook de schaduwzijde van zijn zichtbare publieke rol. Als de besmettingscijfers in augustus 2020 opnieuw oplopen, voert Friedrich in het UMCG de mondmaskerplicht weer in. In de krant zegt hij dat 


\section{'Zorg en preventie zijn vanaf deze crisis een Europees vraagstuk'}


14 de mondmaskerplicht in heel Nederland gaat komen. Boze burgers sturen mails en brieven. 'Mensen zien je als vijand, omdat hun vrijheid wordt beperkt. Het vervelendste vond ik de brieven die mensen onder je voordeur schuiven. Dat voelt onveilig, ook voor je familie die er niets mee te maken heeft. Dat is wel een leermoment.'

\section{Tweede golf}

Elke coronagolf heeft een eigen verhaal. De tweede coronagolf komt veel eerder dan verwacht. In augustus springen de signaalwaardes op het nationale coronadashboard al op rood, maar niemand doet echt wat. Friedrich: 'De tweede golf ging van Spanje, via Frankrijk en België naar Amsterdam, Rotterdam en Den Haag. Het virus reisde mee met studenten die op vakantie waren gegaan. In vakantiehubs mengden zij met elkaar. Mobiliteit en mixen, dat is ideaal voor het virus.'

Eerder dan in de buurlanden gaan in Nederland de universiteiten in september alweer open. 'De sociale verwevenheid van de studentenverenigingen is in Nederland ook veel groter dan in Duitsland. Dat is een groot goed, maar maakt het voor het virus makkelijk. De studentensteden werden de hotspots. In het UMCG droegen alle geneeskundestudenten mondmaskers. We hebben ze aangesproken op hun verantwoordelijkheid om te voorkomen dat het virus via hen kwetsbare patienten zou besmetten.'

In die tweede golf manifesteert zich een bestuurlijke zwakte van het Nederlandse zorgstelsel, stelt Friedrich. Gezondheidszorgbeleid is op nationaal niveau georganiseerd. De landelijke alarmbellen zijn gemiddelden voor het hele land. Het gemiddelde kan nog onder een kritische grens zijn, maar daarmee zie je de brandhaarden niet in de grote steden. Nederland mist een bestuurlijk systeem om landelijk beleid op regionaal niveau te finetunen. 'In Italië en Duitsland gebeurt dat wel. In de deelstaat Noordrijn-Westfalen, met 18 miljoen inwoners vergelijkbaar met Nederland, zijn er wel 54 Kreisen. In de ene Kreis gaan de scholen en horeca dicht, in de andere niet.'

\section{Nieuwe regio's}

Nederland zal gezondheidsbeleid op een nieuw regionaal niveau moeten gaan organiseren, is de overtuiging van Friedrich. 'Dat het niet regionaal gebeurt, komt doordat het bestuurlijk niet bestaat. Daarnaast is er een psychologische blokkade. Nederland is niet gewend om regionaal te denken.

\section{ALEX FRIEDRICH}

studeerde geneeskunde in Würzburg, Coimbra (Portugal) en Rome. Hij beheerst acht

Europese talen: Duits, Grieks, Nederlands, Spaans, Engels, Italiaans, Frans en Portugees.

Hij specialiseerde zich is in zijn vakgebied tot arts-microbioloog en een vooraanstaand wetenschapper. Hij won diverse wetenschapsprijzen waaronder in 2019 de prestigieuze Robert Koch-prijs voor ziekenhuishygiëne en infectiepreventie. Van 2006-2010 was hij chef de clinique van het Instituut voor Hygiëne van het Universitätsklinikum Münster.
In 2011 werd hij hoofd van de afdeling Medische preventie in het UMCG. Sinds april 2020 is hij lid van het Outbreak Management Team. Hij verlaat het UMCG op 1 oktober en gaat op 1 januari 2022 aan de slag als bestuursvoorzitter van het Universitätsklinikum Münster. microbiologie en infectie-

Maar Nederland is te groot voor landelijk beleid en de provincies zijn te klein. Een regio met 1,5 tot 3 miljoen inwoners is de ideale eenheid voor acteren in de zorg, ook voor preventie.'

Voor Nederland denkt Friedrich aan vijf hoofdregio's: West, Noord, Zuid, Oost en Centrum. Per regio zijn er vijf veiligheidsregio's voor maatwerk. 'Het werkt niet als alleen de burgemeester van Amsterdam een maskerplicht invoert in een paar straten. Maar als heel regio West medio augustus in lockdown was gegaan, had je de toename van de tweede golf in het hele land kunnen beperken. Hit hard and early.'

Critici op regionaal beleid wijzen naar Europa als schrikbeeld. Als elke regio, net als elke EU-lidstaat, zijn eigen gang gaat, wordt het chaos. 'Je moet de gezondheidszorg regionaal organiseren, zonder de landelijke afstemming los te laten', is de overtuiging van Friedrich. 'Dat moet ook binnen Europa gebeuren. Het coronavirus kent geen grenzen. Het reist mee met toeristen en vrachtwagenchauffeurs. Als lidstaten hun beleid niet goed afstemmen, gaat het virus als een golf door Europa. Dat maakt ons zwak en kwetsbaar. Als Nederland op 26 juni alles versoepelt en dat niet afstemt met de buurlanden, wordt Nederland een hotspot in vakantietijd.'

Gezondheidsbeleid, preventie en infectiebestrijding, de uitvoering moet allemaal op regionaal niveau gebeuren in heel Europa. 'Europa telt 350 tot 400 gezondheidszorgregio's. Het is helemaal niet ingewikkeld om daar beleid voor te coördineren. De EU-lidstaten hebben daarin nog wel een grote rol. Zij zouden dat moeten faciliteren. Zij hebben het geld en de macht, maar ze missen de efficiency voor effectief beleid op regionaal en continentaal niveau.'

\section{In één schuitje}

Het finetunen moet vooral niet in Brussel, stelt Friedrich. 'Brussel is niet Europa, wij zijn 

samenwerken en dat is ook gebeurd. Ook voor de inhaalzorg zie ik mogelijkheden.'

De EU-lidstaten zijn in de coronapandemie te veel op zichzelf gericht. Er is niet voldoende vertrouwen en culturele sensitiviteit om snel van elkaar te leren, vindt Friedrich. 'Neem het onderzoek van mijn Italiaanse collega Andrea Crisanti. Hij toonde in de eerste golf al aan dat je in een kleine stad de $\mathrm{R}$ binnen twee weken van 2,4 naar 0,5 kunt krijgen als je iedereen test. Daarmee voorkom je immers dat asymptomatisch geïnfecteerden het virus doorgeven. Griekenland en sommige deelstaten in Duitsland pakten zijn aanpak op. Maar Nederland nam de resultaten pas een half jaar later serieus toen hij had gepubliceerd in Nature. Waarom? Hoeveel evidentie heb je nodig? We moeten in een pandemie sneller bewijs van elkaar accepteren.'

\section{Meer zorgcapaciteit}

Het coronavirus zal, net als het griepvirus, niet meer verdwijnen. Het zal met de seizoenen meebewegen. De varianten die nu ontstaan in de winter op het Zuidelijk halfrond, komen in het najaar en de winter naar het Noordelijk halfrond, waarschuwt Friedrich. 'Dat hoeft niet opnieuw een tsunami te zijn, want de vaccins zijn de gamechanger. Maar niet iedereen is gevaccineerd en bij sommige mensen werkt het immuunsysteem niet goed. Gevaccineerden kunnen anderen nog besmetten, dus je zult wel veel moeten testen.' Dat het coronavirus blijft, heeft grote gevolgen voor de gezondheidszorg. Nederland heeft 15 tot 20 procent meer zorgcapaciteit nodig, anders kan Nederland de pieken van nieuwe corona- en andere virusgolven niet opvangen. Dan neemt de inhaalzorg weer toe, meent de arts-microbioloog. 'We hebben met covid-19 er een ziekte bij die niet een andere vervangt. Nieuwe patiënten zoals mensen met long-covid en patiënten met een onderliggende ziekte die Sars-CoV-2 geïnfecteerd zijn. Verder zijn er bekende ziektes, zoals hartinfarct, die nu het coronavirus als oorzaak kunnen hebben. De zorg moet er dus overal een stukje bij krijgen. Dat betekent dat je meer bedden en meer personeel nodig hebt. De testcapaciteit moet structureel omhoog en de GGD'en hebben meer geld nodig voor de publieke gezondheid. Het Nederlandse zorgstelsel had al te weinig vet op te botten. Er is de laatste decades te veel ingezet op efficiency. We moeten terug naar normale efficiency.'

Maar Nederland hoeft niet per se zelf de capaciteit met 15 tot 20 procent te verhogen. Voor een deel kan Nederland de overcapaciteit in België en Duitsland gebruiken. Friedrich is groot voorstander van 'grensloze' zorg. Landen moeten niet wachten op een volgende crisis, maar in vredestijd langdurige en structurele afspraken maken. 'Enschede en Gronau hebben allebei een groot ziekenhuis en liggen op 10 kilometer van elkaar. Maak afspraken over diagnostiek en behandelingen. Als de een wachtlijsten heeft, kan de ander helpen. Bespreek hoe je communiceert en de kwaliteit garandeert. Organiseer visitaties over en weer.'

\section{Zonder grenzen}

Als nieuwe bestuursvoorzitter van het Universiteitsziekenhuis in Münster, wil Friedrich zijn 'Euregionale' ambities op een hoger niveau tillen. In de regio met Munster, Oldenburg, Groningen, Enschede en Nijmegen wonen negen miljoen inwoners. Friedrich wil Europa laten trillen met zorg zonder grenzen. De beste zorg op de juiste plek, en wanneer dat beter is voor patiënten, net over de grens. 'Nederland kan gebruikmaken van de Duitse overcapaciteit op IC-bedden. Duitse kinderen met een hersentumor kunnen protonentherapie in Groningen krijgen. Patiënten die revalideren van een heupoperatie kunnen dat in Duitse revalidatiecentra doen.'

Het overwinnen van blokkades op het gebied van financiering, wetten en communicatie lukt alleen als iedereen mee werkt, realiseert Friedrich.

'Maar zorg en preventie zijn vanaf deze crisis een Europees vraagstuk. We moeten samen bouwen aan de Europese zorg van de toekomst. Waar kan dat beter dan in Münster, de stad van de vrede?' 


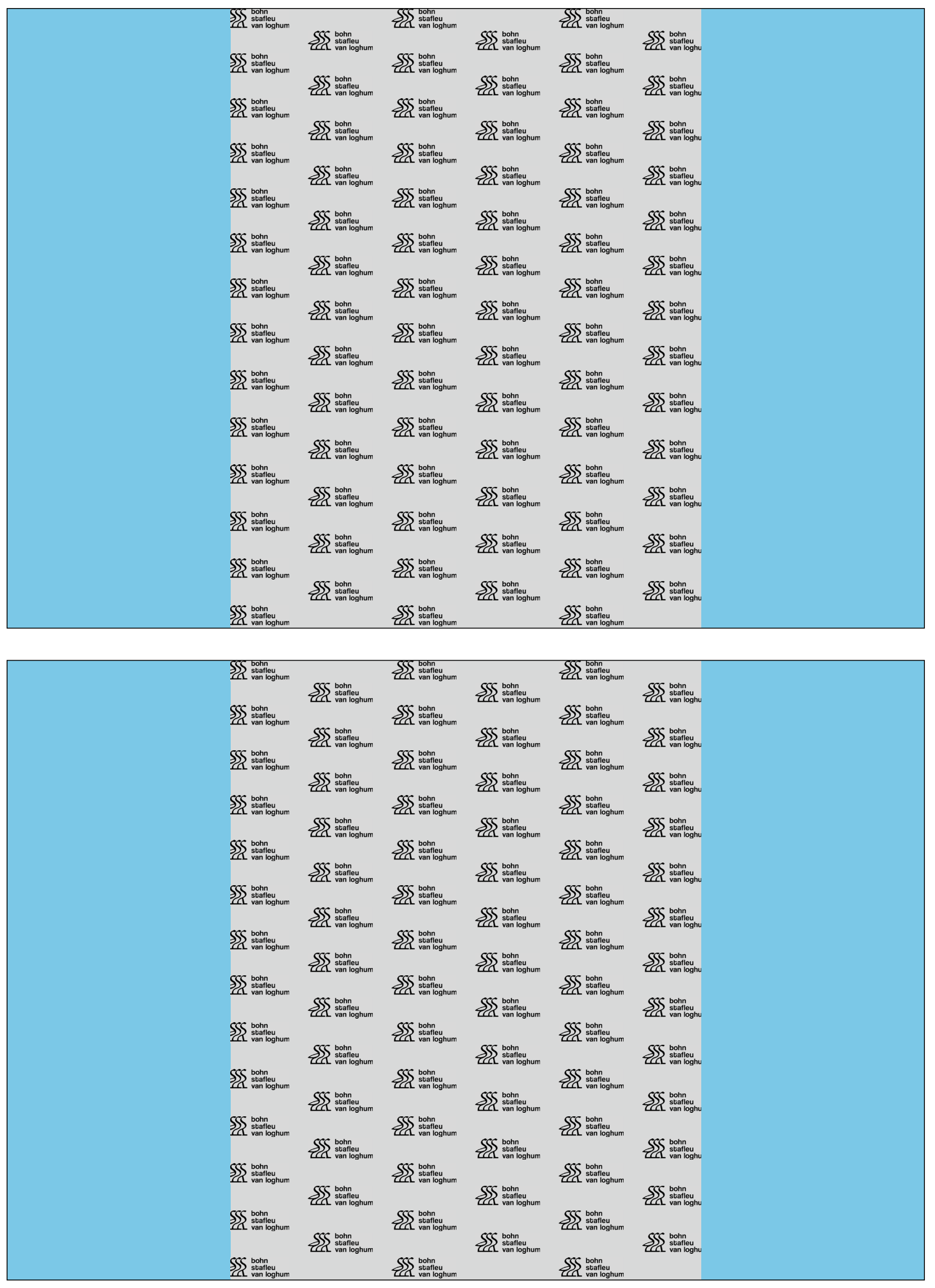


$\iint_{\text {bohn }}^{\text {stafleu }}$

L van loghum

S bohn stafleu

Lan loghum

SSS bohn

PS stafleu

van loghum

of bohn

) stafleu

L van loghum

SSS bohn

II van loghum

Sohn

stafleu

L van loghum

bohn

stafleu

L van loghum

L van loghum

bohn

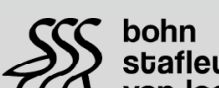

CSS bohn

IL van loghum

SSS lohn

IL van loghum

SS lafleu

SSS bohn

SSS bohn

CL van loghum

SSS bohn

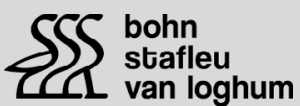

SSS bohn

IL van loghum

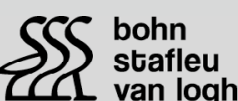

SSS bohn

II van loghum

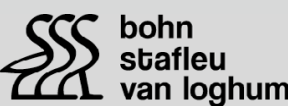

CI van loghum

SSS bohn

SSS bohn

CI van loghum

SSS bohn

CI van loghum

IL van loghum

SSG bohn

8) stafleu

PC stafleu

SSS bohn

CI van loghum

SCS bohn

CIL van loghum

SSS lohn

II van loghum

II van loghum

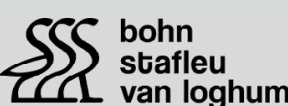

SSS bohn

CL van loghum

SSS bohn

van loghum

CSS bohn

LI van logh

van loghum

cce bohn

PD stafleu

SCS bohn

CI $\begin{aligned} & \text { stafleu } \\ & \text { van loghum }\end{aligned}$

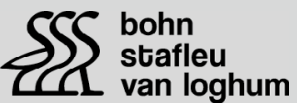

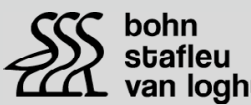

SSS bohn

Stafleu

van loghu

SSS bohn

II van loghum

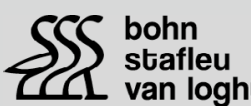

SSS bohn

SSS bohn

CL van loghum

SSS bohn

D) stafleu

Cl van loghum
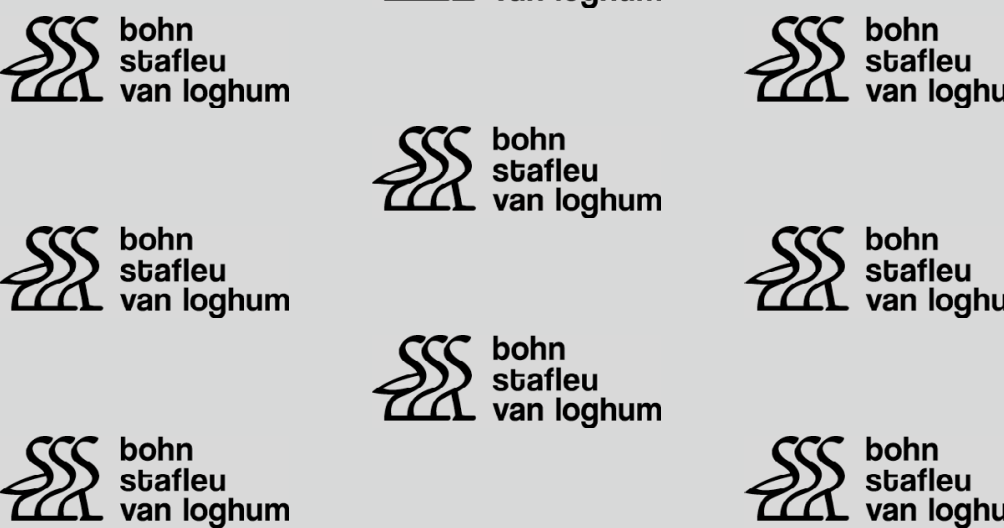
bohn
stafleu Cl van loghum

CSC bohn stafleu van loghum
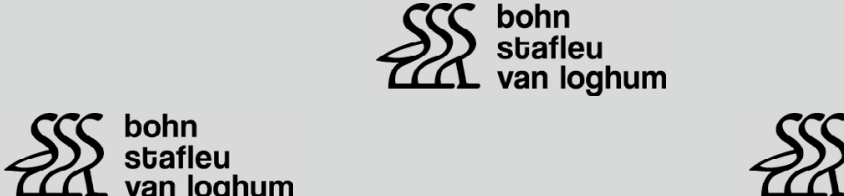

bohn stafleu van loghum

SSS bohn

van loghum

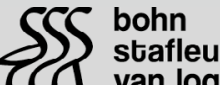

van loghum

SSS lohn CL van logh

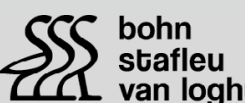

SSS bohn stafleu van loghu bohn

D stafleu

Stafleu

Lan loghum

Stafleu

L van loghum

8 bohn

Stafleu

L van loghum

SSS bohn

IL van loghum

3 bohn

stafleu

Lan loghum

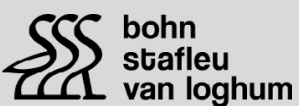

SSS bohn

CI van loghum

SSS bohn

C) stafleu

SSS bohn stafleu
van loghum

bohn

stafleu

L van loghum

cCS bohn

¿) stafleu

of bohn

stafleu

L van loghum

SSS bohn

CL van loghum

SCS bohn

Cohn

L van loghum 